\title{
CAPAIAN KINERJA BERDASARKAN REALISASI KEUANGAN DAN REALISASI FISIK PADA DINAS KEBUDAYAAN DAN PARIWISATA PROVINSI KEPULAUAN BANGKA BELITUNG
}

\author{
Ana Oktaria Indah ${ }^{1)}$ Dr. Devi Valeriani, S.E.,M.Si ${ }^{2)}$ \\ ${ }^{1)}$ Mahasiswa Fakultas Ekonomi Universitas Bangka Belitung \\ ${ }^{2)}$ DosenFakultasEkonomiUniversitas Bangka Belitung \\ E-mail: Anaindah.elf10@gmail.comTelp/Hp; 08974168311
}

\begin{abstract}
ABSTRAK
Anggaran merupakan estimasi kerja yang hendak dicapai selama periode tertentu yang dinyatakan dalam ukuran financial, Mardiasmo (2009). Melalu realisasi fisik dan keuangan pelaksanaan kegiatan yang berhubungan dengan segala aktivitas kegiatan dan proyek dana keuangan di masa mendatang sesuai dengan alokasi dananya, Mulyadi (2007). Realisasi baik fisik maupun keuangan diperlukan untuk mengetahui capaian kinerja dinas kebudayaan dan pariwisata dalam rencana kerja yang telah dibuat. Tujuan penelitian adalah untuk melihat capaian kinerja berdasarkan realisasi fisik dan keuangan pada dinas kebudayaan dan pariwisata provinsi kepulauan bangka belitung tahun 20142018. Data yang digunakan dalam penelitian ini merupakan data sekunder selama periode tahun 20142018. Analisis data yang digunakan merupakan analisis deskriptif dengan penyajian data menggunakan grafik dan tabel. Berdasarkan hasil pembahasan yang telah diuraikan, dapat dilihat bahwa capaian kinerja dinas kebudayaan dan pariwisata tidak mengalami peningkatan yang signifikan setiap tahunnya tetapi mengalami fluktuasi cenderung meningkat.
\end{abstract}

Kata Kunci: Capaian Kinerja, Realisasi Fisik dan Keuangan, Bangka Belitung

\section{PENDAHULUAN}

Keuangan Daerah adalah semua hak dan kewajiban Daerah dalam rangka penyelenggaraan Pemerintahan Daerah yang dapat dinilai dengan uang serta segala bentuk kekayaan yang dapat dijadikan milik Daerah berhubung dengan hak dan kewajiban Daerah tersebut. Dalam Peraturan Pemerintah nomor 12 tahun 2019 tentang Pengelolaan Keuangan Daerah Keuangan Daerah adalah semua hak dan kewajiban Daerah dalam rangka penyelenggaraan Pemerintahan Daerah yang dapat dinilai dengan uang serta segala bentuk kekayaan yang dapat dijadikan milik Daerah berhubung dengan hak dan kewajiban Daerah tersebut. Pengelolaan Keuangan Daerah adalah keseluruhan kegiatan yang meliputi perencanaan, penganggaran, pelaksanaan, penatausahaan, pelaporan, pertanggungjawaban, dan pengawasan Keuangan Daerah. Dalam rangka pengelolaan keuangan daerah yang akuntabel dan transparan, pemerintah daerah wajib menyampaikan pertanggungjawaban berupa: (1) laporan realisasi; (2) neraca; (3) laporan arus kas; (4)catatan atas laporan keuangan. Perangkat Daerah (PD) merupakan unsur penyelenggara pemerintahan daerah 
yang dalam upaya mencapai keberhasilannya perlu didukung dengan perencanaan yang baik sesuai dengan visi dan misi organisasi. Pendekatan yang dilakukan adalah melalui perencanaan strategis yang merupakan serangkaian rencana tindakan dan kegiatan mendasar yang dibuat untuk diimplementasikan oleh organisasi dalam rangka pencapaian tujuan organisasi yang telah ditetapkan sebelumnya. Perencanaan strategis diperlukan karena sasaran organisasi diarahkan kepada kepentingan masyarakat (Consumer driven oriented). Mengacu kepada Undang-Undang Nomor 23 Tahun 2014 mengamanatkan bahwa setiap Perangkat Daerah (PD) diwajibkan menyusun rencana strategis yang selanjutnya disebut Renstra PD. Yang mana Renstra PD memuat visi, misi, tujuan, strategi, kebijakan, program dan kegiatan pembangunan sesuai dengan tugas dan fungsinya, berpedoman pada RPJMD dan bersifat indikatif. (Rencana Strategis Dinas Kebudayaan dan Pariwisata Tahun 2017-2022).

Realisasi fisik dan keuangan yang mencapai target yang diinginkan menandakan bahwa rencana kerja yang disusun, dibuat, dan diinginkan melalui program-program yang direncanakan dan dilaksanakan maka tercapai kinerja yang baik. Terlaksananya program-program yang direncanakan menandakan tercapainya kinerja melalui realisasi fisik dan keuangan sebaliknya apabila realisasi anggaran melalui realisasi fisik dan keuangan tidak mencapai target maka menandakan capaian kinerja yang buruk.

Penelitian ini meneliti data belanja langsung 3 bidang pada dinas kebudayaan dan pariwisata Provinsi Kepulauan Bangka Belitung selama 5 tahun yaitu, (1) Pelayanan administrasi perkantoran, (2) Pengembangan destinasi pariwisata, (3) Program pengembangan pemasaran pariwisata, dengan pagu anggaran dan realisasi sebagai berikut :

Program pelayanan administrasi perkantoran dengan APBD-P dari tahun 2014-2018 mengalami fluktuasi cenderung meningkat dari tahun 2014 sebesar Rp. 2.085.303.000 dengan realisasi keuangan sebesar 81,74 persen dan realisasi fisik sebesar 95,58 persen. Dan tahun 2018 APBD-P sebesar Rp. 5.091.452.801 dengan reallisasi keuangan sebesar 87,24 persen dan realisasi fisik sebesar 100 persen. Sedangkan untuk program pengembangan destinasi pariwisata dengan APBDP dari tahun 2014-2018 juga berfluktuasi cenderung meningkat dari tahun 2014 sebesar Rp. 146.700.000 dengan realisasi keuangan sebesar 99,01 persen dan realisasi fisik 100 persen dan meningkat ditahun 2018 dengan pagu anggaran sebesar Rp. 1.709.261.000 dengan realisasi keuangan sebesar 76,23 persen dan realisasi fisik 100 persen. Kemudian program pengembangan pemasaran pariwisata dengan APBD-P mengalami fluktuasi cenderung meningkat dari tahun 2014 sebesar Rp. 1.902.682.000 dengan realisasi keuangan sebesar 78,19 persen dan realisasi fisik sebesar 90,23 persen dan di tahun 2018 pagu anggaran sebesar Rp. 3.579.524.000 dengan realisasi keuangan sebesar 86,86 persen dan realisasi fisik sebesar 100 persen.

Berdasarkan data Anggaran belanja langsung dinas kebudayaan dan pariwisata Kepulauan Bangka Belitung, maka perlu diketahui capaian kinerja berdasarkan belanja langsung pada tiga 
bidang di dinas kebudayaan dan pariwisata Kepulauan Bangka Belitung. Penelitian ini akan fokus melihat tentang Capaian Kinerja berdasarkan Realisasi Keuangan dan Realisasi Fisik pada Dinas Kebudayaan dan Pariwisata Provinsi Kepulauan BangkaBelitung Tahun 2014-2018.

\section{TINJAUAN PUSTAKA}

\subsection{Konsep APBD}

Anggaran daerah merupakan rencana keuangan yang menjadi dasar dalam pelaksanaan pelayanan publik. Di Indonesia, dokumen anggaran daerah disebut Anggaran Pendapatan dan Belanja Daerah (APBD), baik untuk provinsi maupun kabupaten dan kota. Anggaran Pendapatan dan Belanja Daerah (APBD) pada hakekatnya merupakan salah satu instrumen kebijakan yang dipakai sebagai alat untuk meningkatkan pelayanan umum dan kesejahteraan masyarakat di suatu daerah..

\subsection{Capaian Kinerja}

Rozai dan Subagio (2015) capaian kinerja pelaksanaan anggaran atau Capaian kinerja keuangan menggambarkan besarnya alokasi dan penyerapan anggaran yang digunakan untuk mencapai target kinerja. Sedangkan Whittaker (2000) mengatakan bahwa pengukuran kinerja merupakan suatu alat yang digunakan untuk meningkatkan kualitas pengambilan keputusan dan akuntabilitas.

\subsection{Pentingnya Mengukur Capaian Kinerja Pelaksanaan Anggaran}

Hasil pengukuran kinerja adalah besarnya dana anggaran dengan realisasinya. Dengan perbandingan tersebut dapat diketahui celah kinerja (Performance Gap), yang selanjutnya dianalisis untuk mengetahui penyebab ketidakberhasilan, sehingga dapat ditetapkan suatu strategi guna peningkatan kinerja di masa mendatang (Performance Improvement). Dari hasil pengukuran kinerja tersebut, dapat disimpulkan tingkat keberhasilan dari target yang ditetapkan terlihat dari pencapaian target indikator kinerja kegiatan dan program.

\subsection{Realisasi Keuangan dan Realisasi Fisik}

Mulyadi (2007) mengatakan Realisasi fisik dan keuangan adalah pelaksanaan kegiatan yang berhubungan dengan segala aktivitas kontruksi dan proyek dana keuangan di masa mendatang sesuai dengan alokasi dananya.

\subsection{Penelitian Terdahulu}

\section{Tabel 2.1 Penelitian Terdahulu}

\begin{tabular}{cllrllr}
\hline No & & \multicolumn{2}{c}{ Judul } & Metode Analisis & \multicolumn{2}{c}{ Hasil } \\
\hline 1. & Laely & Analisis Pengeluaran & uji normalitasdata & Berdasarkan r penelitian \\
& Purnamasari & Anggaran & Terhadap & kolmogorov, & yang dilakukan oleh penulis \\
& $(2019)$ & Capaian & Kinerja & korelasipearson & mengenai & Analisis \\
& & Keuangan & & product moment, & Pengeluaran & Anggaran
\end{tabular}


JURNAL MANAJEMEN KOMPETEN

Vol. 3 No.2 Desember 2020, 1-13

$\begin{array}{llr}\text { dan koefisien } & \text { Keuangan } & \text { Terhadap } \\ \text { determin } & \text { Capaian Kinerja Keuangan } \\ & \text { pada } & \text { Kecamatan } \\ & \text { Ujungberung Kota dengan } \\ & \text { indikator peningkatan } \\ & \text { pengembangan r sistem } \\ & \text { pelaporan capaian kinerja } \\ & \text { keuangan tahun 2011-2015 } \\ & \text { Bandung, maka dapat } \\ & \text { ditarik kesimpulan yaitu (1) } \\ & \text { Pengeluaran anggaran } \\ & \text { keuangan kecamatan Ujung } \\ & \text { berung kota Bandung dari } \\ & \text { tahun 2011-2015 } \\ & \text { mengalami peningkatan dan } \\ & \text { penurunan sesuai dengan } \\ & \text { kebutuhan di kecamatan } \\ & \text { ujungberung bandung. }\end{array}$

2. Indrawati Monitoring laporan Analisis deskriptif Berdasarkan uraian dan (2018) realisasi fisik dan keuangan anggaran pendapatan dan analisis yang telah di kemukakan maka hasil dari penelitian

belanja daerah.

Sumber : Diolah peneliti, 2019 tentang ,monitoring laporan realisasi fisik dan keuangan APBD Kabupaten pacitan dapat disimpulkan bahwa belum optimalnya laporan realisasi fisik dan keuangan apbd disebabkan keterlambatan waktu penyampaian laporan dan keterlambatan penyerapan anggaran. pada tahun 2017 perangkat daerah yang menyampaikan laporan RFK sesuai waktu yang ditetapkan sebanyak 25-36 perangkat daerah atau $49,02 \%-70,59 \%$.

\section{METODE}

\subsection{Jenis Penelitian}

Jenis penelitian yang digunakan dalam penelitian ini merupakan penelitian deskriptif Kuantitatif. Deskriptif kuantitatif adalah penelitian yang bertujuan untuk mendeskripsikan atau menjelaskan peristiwa atau suatu kejadian yang terjadi dalam bentuk angka-angka (Sudjana, 2013)..

\subsection{Jenis dan Sumber Data}


Jenis data yang digunakan dalam penelitian ini merupakan data kuantitatif dan data sekunder. Data kuantitatif adalah jenis data yang dapat diukur atau dihitung secara langsung, yang berupa informasi atau penjelasan yang dinyatakan dengan bilangan atau berbentuk angka. (Sugiyono, 2010).

Sumber data dalam penelitian ini merupakan data primer dan data sekunder. Data primer adalah data yang mengacu pada informasi yang diperoleh dari tangan pertama (Sekaran, 2011). Data sekunder adalah data yang mengacu pada informasi yang dikumpulkan dari sumber yang telah ada.

\section{HASIL DAN PEMBAHASAN}

\subsection{Perkembangan APBD-P dan Realisasi Program Pelayanan Administrasi Perkantoran Tahun 2014-2018.}

Program Pelayanan Administrasi Perkantoran merupakan program berupa pelayanan atau penyedia jasa. Seperti Penyediaan Jasa Surat Menyurat dipergunakan untuk kegiatan ketatausahaan/kesekretariatan yang berhubungan dengan administrasi surat menyurat danpenyediaan jasa peralatan dan perlengkapan kantor, penyewaan peralatan dan perlengkapan kantor yang digunakan untuk pelayanan administrasi perkantoran/kesekretariatan.

Tabel 4.1

APBD-P dan Realisasi Program Pelayanan Administrasi Perkantoran Tahun 2014-2018

\begin{tabular}{lllccc}
\hline $\begin{array}{c}\text { Nama } \\
\text { Program/ } \\
\text { Kegiatan }\end{array}$ & Tahun & & APBD-P & $\begin{array}{c}\text { Keuangan } \\
(\%)\end{array}$ & $\begin{array}{c}\text { Fisik } \\
(\%)\end{array}$ \\
\hline Program & 2014 & $\mathrm{Rp}$ & 2.085 .303 .000 & 81.74 & 100 \\
pelayanan & 2015 & $\mathrm{Rp}$ & 2.053 .585 .000 & 74.54 & 100 \\
administrasi & 2016 & $\mathrm{Rp}$ & 1.899 .927 .500 & 81.73 & 100 \\
perkantoran & 2017 & $\mathrm{Rp}$ & 2.175 .758 .500 & 83 & 100 \\
& 2018 & $\mathrm{Rp}$ & 5.091 .452 .801 & 87.24 & 100 \\
\hline
\end{tabular}

Sumber Data : Dinas Kebudayaan dan Pariwisata Provinsi Kepulauan Bangka Belitung (Diolah, 2019)

Tabel 4.1 Menunjukkan anggaran dan realisasi program pelayanan administrasi perkantoran dengan pagu dana ditahun 2014 sebesar Rp 2.085.303.000 dengan realisasi keuangan sebesar 81,74 persen dan realisasi fisiknya sebesar 100 persen. Kemudian tahun 2015 dengan anggaran sebesar Rp 2.053.585.000 dengan realisasi keuangan 74,45 persen dan realisasi fisiknya sebesar 100 persen. Untuk tahun 2016 anggaran sebesar Rp 1.899.927.500 dengan realisasi keuangannya sebesar 81,73 persen dengan realisasi fisiknya sebesar 100 persen. Anggaran untuk tahun 2017 sebesar Rp 2.175.758.500 dan realisasinya sebesar 83 persen dan realisasi fisiknya sebesar 100 persen. Kemudian tahun 2018 anggaran sebesar Rp 5.091.452.801 dengan realisasi keuangannya sebesar 87,24 dengan realisasi fisiknya sebesar 100 persen. Rata-rata anggaran program administrasi perkantoran selama lima tahun terakhir sebesar Rp 2.661.205.360, rata-rata realisasi fisiknya sebesar 100 persen dan keuangan sebesar 81,65 persen. 


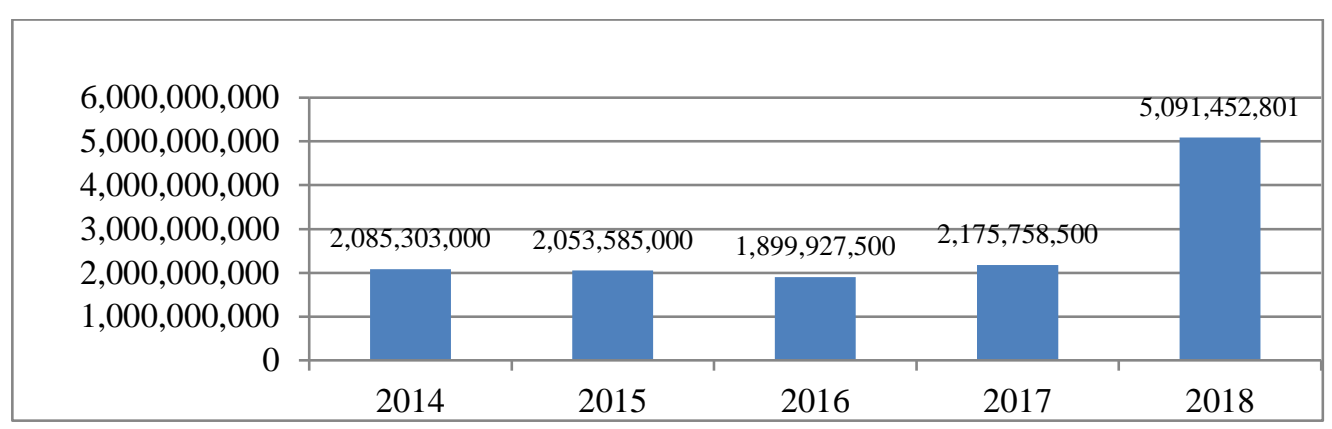

Sumber Data : Dinas Kebudayaan dan Pariwisata Provinsi Kepulauan Bangka Belitung (Diolah, 2019)

\section{Grafik 4.1 APBD-P Program Pelayanan Administrasi Perkantoran tahun 2014-2018}

Grafik 4.1 Menunjukkan anggaran program pelayanan administrasi dari tahun 2014 sampai 2018 mengalami fluktuasi cenderung meningkat dikarenakan bertambahnya kegiatan setiap tahunnya. Anggaran tertinggi ada pada tahun 2018 sebesar Rp. 5.091.452.801 dan terendah tahun 2016 dikarenakan adanya program yang tidak terlaksana dan dana yang digunakan sebesar sebesar Rp. 1.899.927.500.

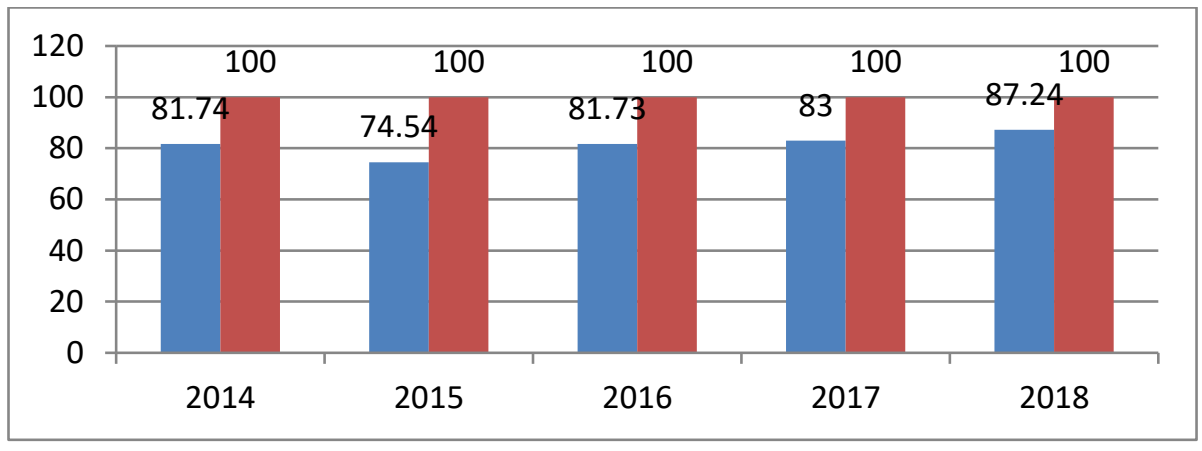

Sumber Data : Dinas Kebudayaan dan Pariwisata Provinsi Kepulauan Bangka Belitung (Diolah, 2019)

\section{Grafik 4.2 Realisasi Keuangan dan Realisasi Fisik Program Pelayanan Administrasi Tahun 2014-2018.}

Grafik 4.2 Menunjukkan realisasi keuangan program pelayanan administrasi dari tahun 2014 sampai 2018 mengalami fluktuasi cenderung meningkat seiring dengan semakin tahun program kegiatan yang di rencanakan bertambah dengan realisasi tertinggi ada pada tahun 2018 sebesar 86,86 persen dan terendah pada tahun 71,35 persen dan untuk realisasi fisik konsisten pada angka 100 persen yang artinya

\subsubsection{Perkembangan APBD-P dan Realisasi Program PengembanganDestinasi Pariwisata}

\section{Tahun 2014-2018}

Bidang Pengembangan Destinasi Pariwisata, memiliki fungsi sebagai berikut:

1.Penyelenggaraan dan pengkoordinasian penyusunan dan penyiapan bahan rumusan kebijakan daya tarik wisata, kawasan strategis pariwisata dan destinasi pariwisata;

2. Penyelenggaraan penyiapan bahan pelaksanaan kebijakan teknis daya tarik wisata, kawasan strategis pariwisata dan destinasi pariwisata; 
3. Penyelenggaraan penyiapan bahanpelaksanaan evaluasi dan pelaporan teknis daya tarik wisata, kawasan strategis pariwisata dan destinasi pariwisata;

Tabel 4.2 APBD-P dan Realisasi Program Pengembangan Destinasi Pariwisata tahun 20142018

\begin{tabular}{lllccc}
\hline $\begin{array}{c}\text { Nama } \\
\text { Program/ } \\
\text { Kegiatan }\end{array}$ & Tahun & & APBD-P & $\begin{array}{c}\text { Reuangan } \\
(\%)\end{array}$ & $\begin{array}{c}\text { Fisik } \\
(\%)\end{array}$ \\
\hline Program & 2014 & $\mathrm{Rp}$ & 784.239 .000 & 84.40 & 100 \\
pengemban & 2015 & $\mathrm{Rp}$ & 1.347 .832 .000 & 53.87 & 100 \\
gan & 2016 & $\mathrm{Rp}$ & 528.906 .000 & 95.06 & 100 \\
destinasi & 2017 & $\mathrm{Rp}$ & 2.764 .437 .625 & 74 & 100 \\
pariwisata & 2018 & $\mathrm{Rp}$ & 1.488 .330 .000 & 74.38 & 100 \\
\hline
\end{tabular}

Sumber Data : Dinas Kebudayaan dan Pariwisata Provinsi Kepulauan Bangka Belitung (Diolah, 2019)

Tabel 4.2 Menunjukkan anggaran dan realisasi program pengembangan destinasi pariwisata di tahun 2014 sebesar Rp 784.239.000 dengan realisasi keuangan sebesar 84,40 persen dan realisasi fisiknya sebesar 100 persen. Kemudian tahun 2015 dengan anggaran sebesar Rp 1.347.832.000 dengan realisasi keuangan 53,87 persen dan realisasi fisiknya sebesar 100 persen. Untuk tahun 2016 anggaran sebesar Rp 528.906.000 dengan realisasi keuangannya sebesar 95,06 persen dengan realisasi fisiknya sebesar 100 persen. Anggaran untuk tahun 2017 sebesar Rp 2.764.437.625 dan realisasinya sebesar 74 persen dan realisasi fisiknya sebesar 100 persen. Kemudian tahun 2018 anggaran sebesar Rp1.488.330.000 dengan realisasi keuangannya sebesar 87,24 persen dengan realisasi fisiknya sebesar 100 persen. Rata-rata anggaran program pengembangan destinasi pariwisata selama lima tahun terakhir sebesar Rp 1.382.748.925, rata-rata realisasi fisiknya sebesar 100 persen dan realisasi keuangannya sebesar 76,34 persen.

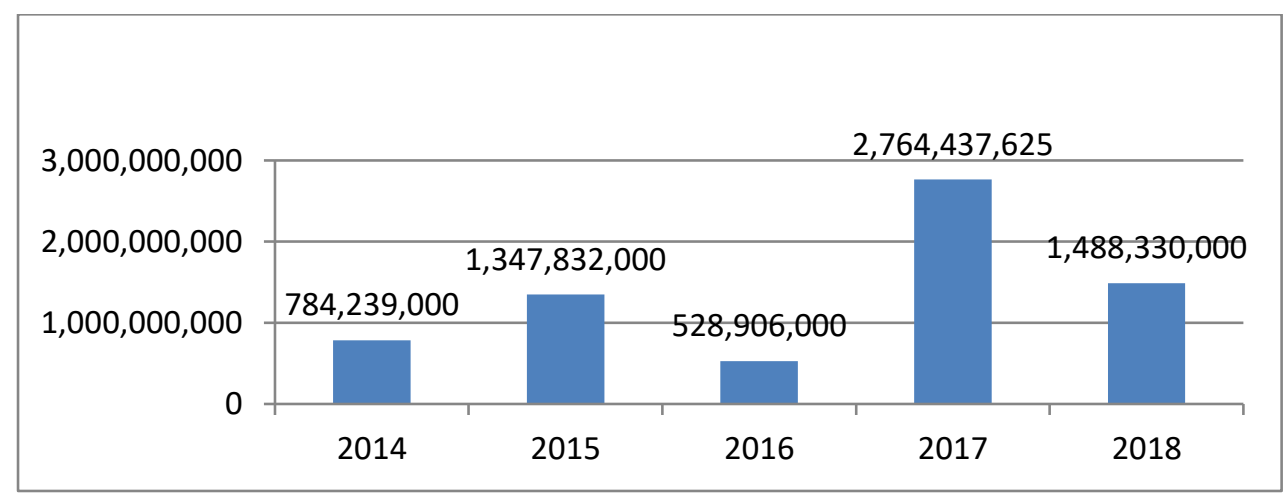

Sumber Data : Dinas Kebudayaan dan Pariwisata Provinsi Kepulauan Bangka Belitung (Diolah, 2019)

Grafik 4.3 APBD-P Program Pengembangan Destinasi Pariwisata Tahun 2014-2018 
Grafik 4.3 menunjukkan anggaran program pengembangan destinasi pariwisati dari tahun 2014 sampai 2018 mengalami fluktuasi cenderung meningkat. Anggaran tertinggi ada pada tahun 2017 sebesar Rp. 2.764.437.625 dan terendah tahun 2016 sebesar Rp. 1.899.927.500.

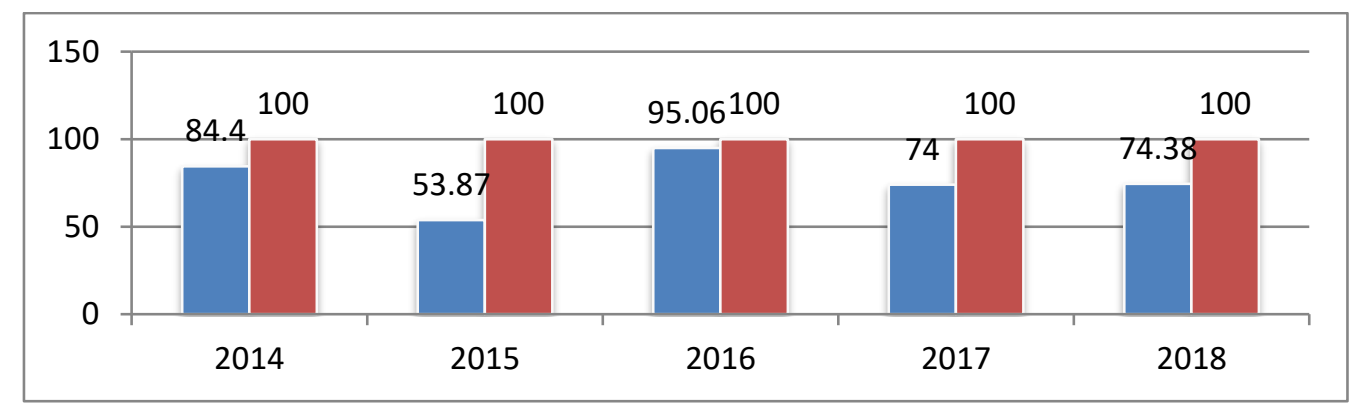

Sumber Data : Dinas Kebudayaan dan Pariwisata Provinsi Kepulauan Bangka Belitung (Diolah, 2019)

\section{Grafik 4.4 Realisasi Keuangan dan Realisasi Fisik Program Pengembangan Destinasi Pariwisata Tahun 2014-2018}

Grafik 4.3 Realisasi keuangan untuk program pengembangan destinasi pariwisata dari tahun 2014 sampai 2018 mengalami fluktuasi cenderung meningkat. Realisasi keuangan tertinggi berada pada tahun 2018 sebesar 95,06 persen dan terendah pada tahun 2015 sebesar 53,87 persen. Realisasi fisiknya konsisten berada di angka 100 persen.

\subsubsection{Perkembangan APBD-P dan Realisasi Program PengembanganPemasaran Pariwisata} Tahun 2014-2018.

Dalam menjalankan tugas Bidang Pengembangan Pemasaran Pariwisata memiliki fungsi, yaitu :

1. Penyelenggaraan dan pengoordinasian penyiapan bahan dan penyusunan rumusan kebijakan analisis pasar pariwisata. promosi pariwisata dan pelayanan infomasi pariwisata;

2. Penyelenggaraan penyiapan bahan pelaksanaan kebijakan teknisanalisis pasar pariwisata, promosi pariwisata dan pelayanan informasi pariwisata;

3. Penyelenggaraan penyiapan bahan pelaksanaan evaluasi dan pelaporan teknis analisis pasar pariwisata, promosi pariwisata dan pelayanan informasi pariwisata;

Tabel 4.3 APBD-P dan Realisasi Program Pengembangan Pemasaran Pariwisata Tahun 2014-2018

\begin{tabular}{cccccc}
\hline $\begin{array}{c}\text { Nama } \\
\text { Program/ } \\
\text { Kegiatan }\end{array}$ & Tahun & & APBD-P & $\begin{array}{c}\text { Keuangan } \\
(\%)\end{array}$ & $\begin{array}{c}\text { Realisasi } \\
(\%)\end{array}$ \\
\hline Program & 2014 & Rp & 1.902 .682 .000 & 78.19 & 100 \\
pengemban & 2015 & Rp & 3.907 .000 .000 & 71.36 & 100 \\
gan & 2016 & Rp & 2.477 .007 .000 & 72.71 & 100
\end{tabular}




$\begin{array}{llllcl}\text { pemasaran } & 2017 & \mathrm{Rp} & 4.116 .890 .200 & 78 & 100 \\ \text { pariwisata } & 2018 & \mathrm{Rp} & 3.579 .524 .000 & 86.86 & 100\end{array}$

Sumber Data : Dinas Kebudayaan dan Pariwisata Provinsi Kepulauan Bangka Belitung (Diolah, 2019)

Tabel 4.3 menunjukkan anggaran dan realisasi program pengembangan pemasaran dari tahun 2014-2018. Di tahun 2014 anggaran sebesar Rp 1.902.682.000 dengan realisasi keuangan sebesar 78,19 persen dan realisasi fisiknya sebesar 100 persen. Kemudian tahun 2015 dengan anggaran sebesar Rp 3.907.000.000 dengan realisasi keuangan 53,87 persen dan realisasi fisiknya sebesar 100 persen. Untuk tahun 2016 anggaran sebesar Rp 2.477.007.000 dengan realisasi keuangannya sebesar 95,06 persen dengan realisasi fisiknya sebesar 100 persen. Anggaran untuk tahun 2017 sebesar Rp 4.116.890.200 dan realisasinya sebesar 74 persen dan realisasi fisiknya sebesar 100 persen. Kemudian tahun 2018 anggaran sebesar Rp 3.579.524.000 dengan realisasi keuangannya sebesar 87,24 persen dengan realisasi fisiknya sebesar 100 persen. Rata-rata anggaran program pengembangan destinasi pariwisata selama lima tahun terakhir sebesar Rp, 3.196.620.640,rata-rata realisasi fiSiknya sebesar 100 persen dan realisasi keuangannya sebesar 77,42 persen.

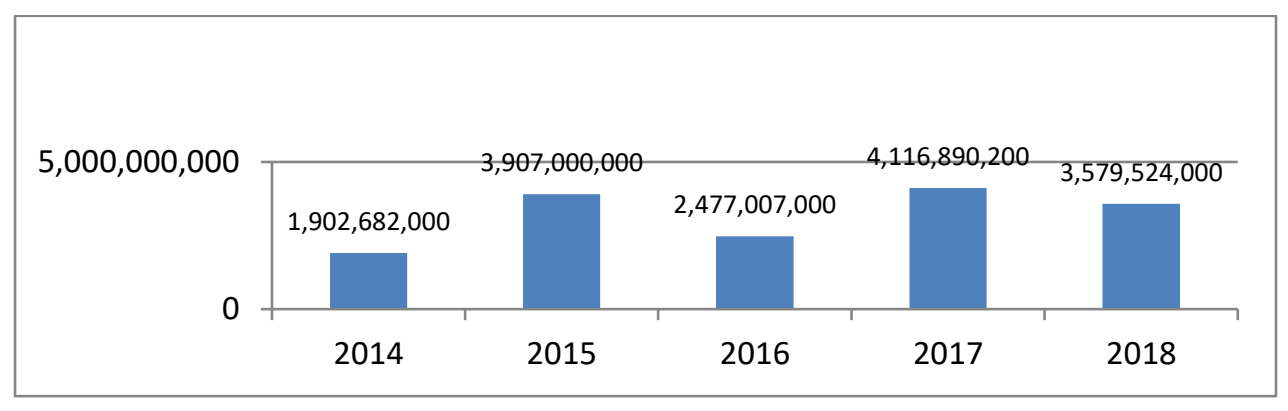

Sumber Data : Dinas Kebudayaan dan Pariwisata Provinsi Kepulauan Bangka Belitung (Diolah, 2019)

\section{Grafik 4.5 APBD-P Program Pengembangan Pemasaran Pariwisata Tahun 2014-2018.}

Grafik 4.5 menunjukkan anggaran program pengembangan destinasi pariwisati dari tahun 2014 sampai 2018 mengalami fluktuasi cenderung meningkat. Anggaran tertinggi ada pada tahun 2017 sebesar Rp. 4.116.890.200 dan terendah tahun 2014 sebesar Rp. 1.902.682.000.

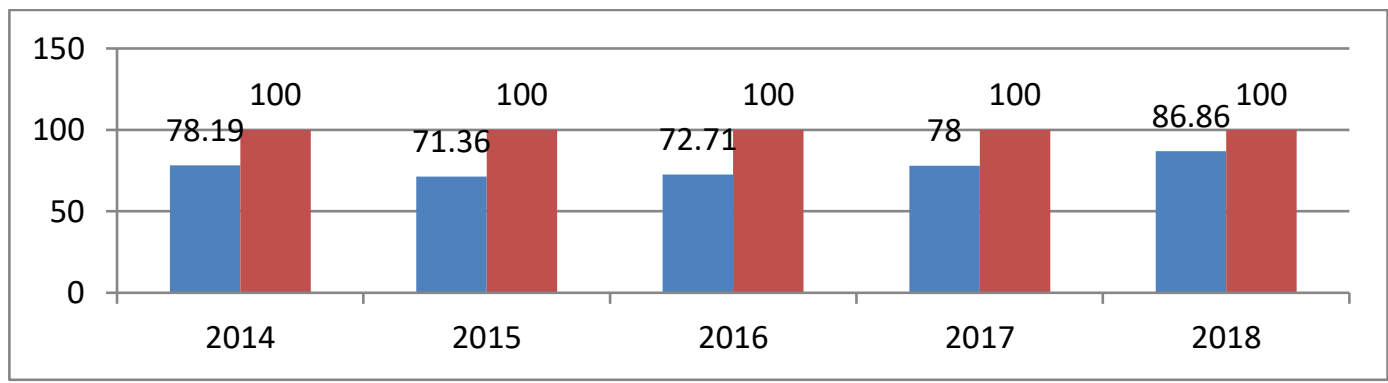

Sumber Data : Dinas Kebudayaan dan Pariwisata Provinsi Kepulauan Bangka Belitung (Diolah, 2019) 
Grafik 4.6 Realisasi Keuangan dan Realisasi Fisik Program Pengembangan Pemasaran Pariwisata Tahun 2014-2018

Grafik 4.6 menunjukkan Realisasi keuangan untuk program pengembangan pemasaran pariwisata dari tahun 2014 sampai 2018 mengalami fluktuasi cenderung meningkat. Realisasi keuangan tertinggi berada pada tahun 2018 sebesar 86,86 persendan terendah pada tahun 2015 sebesar 71,36 persen. Realisasi fisiknya konsisten berada di angka 100 persen.

\subsection{Pembahasan}

4.2.1 Analisis Perkembangan Realisasi Keuangan dan Realisasi Fisik ProgramPelayanan Administrasi Perkantoran.

Realisasi keuangan pada program pelayanan administrasi perkantoran dari tahun 2014-2018 mengalami fluktuasi cenderung meningkat dengan rata-rata 81,65 yang memenuhi standar realisasi yang baik diatas 80 persen. Untuk rata-rata realisasi fisiknya sebesar 100 persen yang dapat dikatakan termasuk realisasi yang baik. Realisasi tahun 2015 dibawah 80 persen sebesar 74,54 persen yang bisa dikatakan kurang baik disebabkan oleh adanya kegiatan dari program pelayanan administrasi perkantoran yang serapan anggarannya berada dibawah 50 persen yang berarti dana yang tersedia untuk kegiatan tersebut tidak teralokasi dengan baik.

\subsubsection{Analisis Perkembangan Realisasi Keuangan dan Realisasi Fisik} ProgramPengembangan Destinasi Pariwisata.

Realisasi keuangan pada program pengembangan destinasi pariwisata dari tahun 2014-2018 mengalami fluktuasi cenderung meningkat selama lima tahun dengan rata-rata 76,34. Realisasi yang berada diatas 80 persen sudah dapat dikatakan baik, namun realisasi dibawah 80 persen dapat dikatakan kurang baik artinya serapan anggaran tidak sesuai dengan dana yang tersedia. Realisasi untuk program pengembangan destinasi pariwisata yang berada di bawah 80 persen disebabkan oleh adanya kegiatan yang tidak terlaksana yaitu :

1. Program Pengembangan Objek Pariwisata Pulau Belitong.

2. Pemberdayaan masyarakat di destinasi pariwisata.

3. Pengembangan dan usaha produk pariwisata.

4. Pemberdayaan masyarakat di destinasi pariwisata.

5. Penyusunan RIRD KSPP Muntok dan sekitarnya..

6. Penyusunan RIRD KSPP Pangkalpinang-Mendobarat-Bangka Tengah dan sekitarnya.

7. Penyusunan RIRD KSPP pulau belitung dan sekitarnya.

8. Pembuatan papan informasi di Daya Tarik Wisata.

9. Pembangunan dan Pengembangan Sarana dan Prasarana di Destinasi Pariwisata. 


\subsubsection{Analisis Perkembangan Realisasi Keuangan dan Realisasi Fisik Program Pengembangan Pemasaran Pariwisata.}

Realisasi keuangan pada program pengembangan destinasi pariwisata dari tahun 20142018 mengalami fluktuasi cenderung meningkat selama lima tahun dengan rata-rata 77,42 . Realisasi yang berada diatas 80 persen sudah dapat dikatakan baik, namun realisasi dibawah 80 persen dapat dikatakan kurang baik artinya serapan anggaran tidak sesuai dengan dana yang tersedia. Realisasi yang dibawah 80 persen pada program pemasaran pariwisata disebabkan oleh :

1. Adanya kegiatan yang tidak terlaksana seperti kegiatan pengembangan pasar dan informasii pariwisata.

2. Kurangnya koodinasi dalam menyusun dan melaksanakan kegiatan.

3. Dilihat masih adanya APBD-P ( Anggaran Pendapatan Belanja Daerah Perubahan) yang artinya masih adanya revisi anggaran menyebabkan jadwal rencana kerja tidak tepat.

\subsection{KESIMPULAN}

Berdasarkan hasil pembahasan yang telah diuraikan, dapat dilihat bahwa capaian kinerja dinas kebudayaan dan pariwisata pada 3 program selama lima tahun mengalami fluktuasi cenderung meningkat pada realisasi keuangan dan konsisten berada diangka 100 persen pada realisasi fisiknya. Realisasi keuangan yang berada diatas 80 persen dapat dikatakan sudah baik artinya serapan anggaran atas dana yang tersedia teralokasi dengan baik dan sudah digunakan cukup baik. Sedangkan realisasi keuangan yang dibawah 80 persen menandakan kurangnya serapan anggaran atas dana yang tersedia. Ada beberapa faktor yang menyebabkan anggaran tidak terserap dengan baik, yaitu adanya kegiatan-kegiatan yang telah direncanakan tidak terlaksana serta kurangnya koordinasi antar bidang dalam melaksanakan kegiatan yang telah direncanakan.

\section{UCAPAN TERIMAKASIH}

Puji syukur penulis panjatkan kepada Tuhan Yang Maha Esa atas Karunia-Nya sehingga dapat menyelesaikan Laporan Kerja Praktik Yang berjudul "Capaian Kinerja Berdasarkan Realisasi Keuangan Dan Realisasi Fisik Pada Dinas Kebudayaan Dan Pariwisata Provinsi Kepulauan Bangka Belitung” dengan tepat waktu. Kuliah Kerja Praktik dilaksanakan dari 10 Juni sampai dengan 9 Agustus 2019. Di dalam penulisan Laporan Kerja Praktik ini penulis ingin mengucapkan banyak terima kasih kepada :

1. Bapak Ahmad sanusi dan Ibu Tri irianti, selaku orang tua atas doa dan dukungannya baik secara moril maupun materiil. 
2. Ibu Dr. Devi Valeriani, S.E.,M.Si, selaku Ketua Jurusan Program Studi Ekonomi sekaligus selaku Dosen Pembimbing Kuliah Kerja Praktik di Universitas Bangka Belitung

3. Bapak Firmansyah,S.H.,M.M., selaku Dosen Pembimbing Lapangan atas saran dan bimbingannya.

4. Serta seluruh teman-teman yang tidak dapat disebutkan satu persatu dalam penelitian ini.

\section{REFERENSI}

Dedi Ismatullah, 2010. Akuntansi Pemererintah, Unit Penerbitdan Percetakan Akademik, YKPN, Bandung.

Dedi Nordiawan, 2010. Akuntansi Sektor Publik, Salemba Empat, Jakarta.

Dinas Kebudayaan dan Pariwisata Provinsi. 2018 Renja (Rencana Kerja)Provinsi Kepulauan Bangka Belitung 2018. Bangka Belitung.

Indrawati, Suprihanto, John and Wibowo, 2018. Monitoring laporan realisasi fisik dan keuangan anggaran pendapatan dan belanja daerah, STIE Widya Wiwaha.

Gubernur kepulauan bangka belitung, Laporan keterangan pertanggung jawaban (LKPJ) akhir tahun 2014.

Gubernur kepulauan bangka belitung, Laporan keterangan pertanggung jawaban (LKPJ) akhir tahun 2015.

Gubernur kepulauan bangka belitung, Laporan keterangan pertanggung jawaban (LKPJ) akhir tahun 2016.

Gubernur kepulauan bangka belitung, Laporan keterangan pertanggung jawaban (LKPJ) akhir tahun 2017.

Gubernur kepulauan bangka belitung, Laporan keterangan pertanggung jawaban (LKPJ) akhir tahun 2018.

Halim, Abdul 2009. Akuntansi sector Publik Akuntansi Keuangan Daerah, Edisi Pertama. Jakarta: Salemba Empat

Komputindo.

Hasyim,Hadi muttaqin, 2009. Contoh skripsi (tugas akhir), Angggaran Belanja Tidak Langsung (bandget accounting).https://muttaqinhasyim.wordp ress.com

diakses 24 agustus 2019.

Jurnal pendidikan akuntansi dan keuangan, STKIP PGRI Sukabumi, Indonesia.
Mahmudi, 2010. Analisis Laporan Keuangan Pemerintah Daerah.Edisi kedua, UPP STIM YKPN, Yogyakarta

Mardiasmo,2002. Otonomi dan manajemen keuangan daerah. Penerbit ANDI Yogyakarta.

Munandar, M. 2000. Budgeting: Perencanaan kerja, Pengkoordinasian Kerja,Pengawasan Kerja. Cetakan Ketigabelas, Yogyakarta: BPFE.

Nordiawan, Dedi. 2012. Anggaran di Suatu Pemerintahan, Salemba Empat,Jakarta.

Nur, Ahmad, 2010. Analisis Laporan Keuangan Pemerintah daerah. Edisi kedua, UPP STIM YKPN, Yogyakarta.

Peraturan Pemerintah Republik Indonesia Nomor 58 Tahun 2005, Keuangan Daerah.

Peraturan Mentri Dalam Negeri Nomor 13 Tahun 2006, “APBD merupakan dasar pengelolaan keuangan daerah dalam masa 1 (satu) tahun anggaran terhitung 1 Januari sampai 31 Desember."

Peraturan Mentri Dalam Negeri Nomor 13 tahun 2006, Belanja Langsung.

Peraturan Mentri Dalam Negeri No. 13 Tahun 2006 Belanja Tidak Langsung.

Peraturan Mentri Dalam Negeri Nomor 21 Tahun 2011 Pasal 1 Ayat 9 "menyatakan bahwa Anggaran Pendapatan dan Belanja Daerah atau yang disebut APBD adalah rencana keuangan tahunan Pemerintahan Daerah yang dibahas dan disetujui bersama oleh Pemerintah Daerah dan Dewan Perwakilan Rakyat Daerah, dan ditetapkan dengan Peraturan Daerah".

Peraturan Mentri Dalam Negeri Pasal 36 No. 21

Tahun 2011, Belanja Langsung.

Peraturan Pemerintah Repulik Indonesia nomor 12 tahun 2019, tentang Pengelolaan Keuangan Daerah.

Peraturan Pemerintah Republik Indonesia Nomor 58 Tahun 2005, Keuangan Daerah. 
JURNAL MANAJEMEN KOMPETEN

Vol. 3 No. 2 Desember 2020, 1-13

Undang-Undang Republik Indonesia No 15 Tahun 2013, Di dalam APBD tercermin kebutuhan masyarakat dengan memperhatikan potensi dan sumber-sumber kekayaan daerah.
Undang-Undang Republik Indonesia Nomor 23 Tahun 2014 mengamanatkan bahwa setiap Perangkat Daerah (PD) diwajibkan menyusun rencana strategis yang selanjutnya disebut Renstra PD. 